\title{
KAS RAHVUSEL ON KOHTA LINGVISTI PEAS?
}

\author{
HELLE METSLANG
}

$\mathrm{P}$ ealkirjaks olev küsimus kasvas välja ühe hea kolleegi reaktsioonist, kui teda oli kutsutud kaasa arutlema seminaril „Humanitaarteaduste roll aru, et keeleteadus ja rahvusküsimus mingis punktis kokku puutuksid: tema ajus olla need täiesti eraldi, vaat et üks ühes ja teine teises poolkeras. Siis nii, nagu skemaatiliselt kujutatud joonisel 1 , kus meile vaatab vastu lingvisti pea, analüütiline mõtlemine vasakus, emotsionaalsed suhtumised paremas poolkeras.

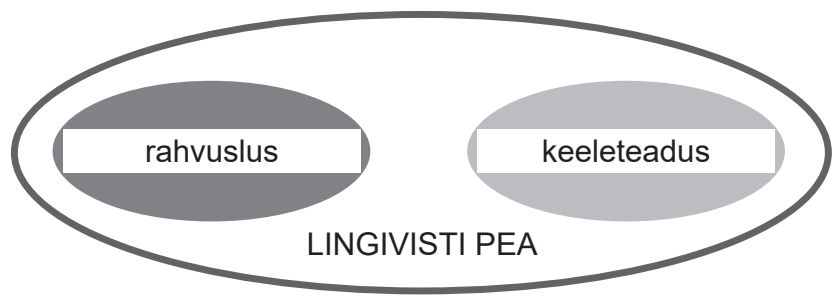

Joonis 1. Keeleteadus ja rahvuslus lingvisti peas.

Küllap leidub neidki päid, mis tegelevad puhta keeleteadusega, ilma et suhtumine keele kõnelejaskonda selle kõrval üldse kohta leiaks (joonis 2).

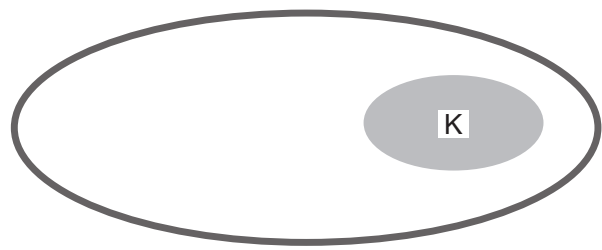

Joonis 2. Keeleteadus lingvisti peas ilma rahvusluseta.

Keelte uurimise eri aegadele ja suundadele mõeldes tundub, et küsimus on laiem: kas suhtumine keelesse kui uurimisobjekti toob kaasa väärtustava suhtumise selle keele kõnelejaskonda ja tema käekäiku, olgu uurija ise kõnelejaskonna liige või mitte. Nimetame analüütilist lähenemist keelele lingvisti pea K-osaks; keele kõnelejaskonnast ja tema loost lähtuvat lähenemist, vaadet etnose identiteedile ja käekäigule aga R-osaks. Püüame välja tuua K- ja R-osa tüüpilisi suhteid keeleuurimise eri aegadel ja suundades ja keele enda paljutahulises olemuses ning lõpuks ka keeleteaduse rolli rahvusriigis. 


\section{Keeleuurija ja keele kõnelejaskond eri aegadel}

Eesti keele esimesed uurijad ja kirjeldajad olid teatavasti sakslased. Eesti keele uurimise esimene periood mahub misjonilingvistika (või laiemalt koloniaallingvistika) mõiste alla. ${ }^{1}$ Seni kirjeldamata või vähe kirjeldatud keelte uurijad tulevad ka tänapäeval enamasti muude rahvaste seast. On neil ka mingi suhe rahvasse, kellelt nad keelematerjali koguvad? Olen kuulnud sümpaatia ja kaasaelamisega oma uuritavate keelte kõnelejatest rääkimas näiteks Bernd Heinet, kes uurib Aafrika keeli; Pier Marco Bertinettot, kes pidas Societas Linguistica Europaea aastakonverentsil Lissabonis 2009. aastal plenaarettekande Boliivias ja Paraguais kõneldavast ajoreo keelest; Dan Everetti filmis „The Grammar of Happiness” (2012) ${ }^{2}$ Brasilias kõneldavast pirahani keelest. Meil Eestis on sugulaskeelte uurijate mureks alati olnud ka keelekõnelejad kamassidest vadjalasteni, nende ajalugu, kultuur, oleviku olukord ja tulevikuperspektiivid; murdeuurijatel on samasugune suhe murrete kõnelejaskonda.

Küllap oli ka XVII-XVIII sajandi saksa hingekarjastest eesti keele kirjeldajatel mingi empaatia eestlaste vastu: see peegeldub näiteks Anton Thor Helle grammatikale lisatud dialoogides, kus Peet ja Hans sõbralikult ja targalt mesilaste pidamise üle vestlevad (Helle 2006 [1732]: 391-404). Seda väikest kokkupuuteala keeleuurimise ja selle taustal ka keelekollektiivi suhtumise vahel kujutab joonis 3. Valgustusajastu ja võrdlev-ajaloolise keeleteaduse tuules XIX sajandi alguseks saabunud estofiilsus kasvatas ühisosa tunduvalt. Ajakirja „Beiträge zur genauern Kenntniß der ehstnischen Sprache” kirjutistes tuleb esile suhtumine eesti keelesse kui eestlaste keelesse: pakub huvi, kuidas eestlased väljenduvad, selgitavad, ütlevad, loovad.

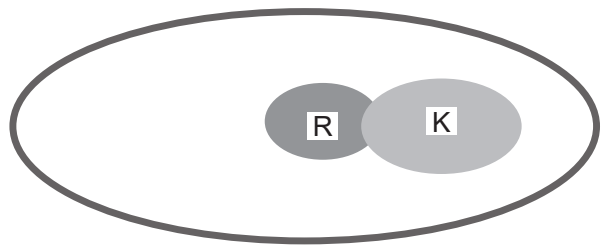

Joonis 3. K- ja R-osa eesti keele uurimise varasel perioodil (XVII-XIX sajand).

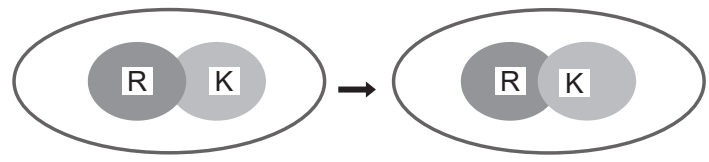

Joonis 4. K- ja R-osa rahvuslikus keeleteaduses XIX-XX sajandil.

XIX-XX sajandil kujunenud eesti rahvusliku keeleteaduse jaoks olid esmatähtsad eesti rahvast teenivad rakenduslikud ülesanded, nagu kirja-

${ }^{1}$ Koloniaallingvistika uuringud on Saksamaal viimastel aastakümnetel hoogustunud, paraku hõlmavad need vaid Euroopast väljaspool toimunut, vt nt Schmidt-Brücken jt 2015.

${ }^{2}$ https://www.youtube.com/watch?v=qsZlY43jI2I (7. I 2018). 
keele kujundamine, korraldamine ja hoole, emakeeleõpetus koolides, registrite kujundamine. Teoreetilisem suunitlus tõusis esiplaanile alles XX sajandi teisel poolel, samal ajal oli suhtumine eesti keelesse kui rahvusliku identiteedi kandjasse keerukal nõukogude ajal kõigile oluline (vt joonist 4). Taastatud iseseisvuse ajal on Eesti keeleteaduse areng hoogustunud, haare laienenud ja pilt kirevam, vaatleme eri tahke ja suundi allpool.

\section{Keele paljutahulisus}

Vaadeldav suhe varieerub ilmselt ka vastavalt sellele, mida ja kuidas lingvist uurib, kui lähedalt seotud on tema uurimisobjekt keele kasutajatega, nende maailmapildi ja oludega nüüdisajal või varem. Keelt on omandanud, edasi kandnud, säilitanud ja muutnud selle keele kõnelejad läbi paljude põlvkondade, keeles on jälgi rahvuse eri tüüpi kogemustest (maailmakäsitus, ajalugu, keelekontaktid, ideoloogiad ja hoiakud jne). Keel on sama ja ei ole ka, ta elab variantide kujul: ühiskeel ja murded, kirjakeel ja argikeel, netikeel, luuleja proosakeel, loitsude ja keelemängude keel, erialakeeled, släng, eripärane keelekasutus peres, sõpruskonnas, igal kõnelejal jne.

Keele võimalikult kõikehõlmava määratluse võib leida Vikipeediast: „Keel on inimeste kasutatav märgisüsteem, kommunikatsiooni või arutluse vahend, mis kasutab sümboleid ja teisi märke ja nende kombineerimise reegleid."3 Nagu näeme, on keelel nii kasutajaga seostuvaid kui ka sellest suhteliselt sõltumatuid tahke. Keele, kasutaja ja keelekollektiivi suhte mitmekesisus kajastub ka funktsioonides, mida keelele omistatakse, nagu tähistusfunktsioon, suhtlusfunktsioon ja sotsiaalne funktsioon.

Tähistusfunktsiooni üksustes võib näha, mida keel mäletab - siin põimub tähistusfunktsioon sotsiaalsega. Sõna- ja väljendivara peegeldab rahva lähemat ja kaugemat ajalugu ja tänapäeva, kultuuri ja maailmapilti. Olgu seejuures võrdluseks näiteks mõningad eri aegadest ja allikatest pärinevad sõnad ja väljendid: kool, pall, pintsel, läbi lugema, välja panema (vanad saksa laenud ja tõlkelaenud), kolp, relv, selmet (Aaviku tehistüved), dekreet, komandeering, sinine leht (nõukogudeaegsed vene laenud ja kujundid), tossud, tagi, rekka (XX sajandi lõpu soome laenud), manus, lähetus, blogi, bränd (tänapäevased tuletised ja inglise laenud). Kaudsemaid peegeldusi võib leida ka grammatikast. Eesti keeles on sõnade nagu pea, külg, juur vormid siirdunud kaassõnadena grammatikasse: laua peal, laua küljes, laua juures. Üks veidi kaugem näide Kongos kõneldavast ngiti keelest: väljendist ibha tähendusega 'kodus' on pärit omamist väljendav kaassõna bhà:
(1) Kamà bhà $d z a$
pealik poss maja
'pealiku maja' (Heine, Kuteva 2002: 175).

Keele suhtlusfunktsiooni üksusi, nagu lausungeid, dialoogi, eri funktsioonidega tekste, uurides uurib lingvist ka keele kõnelejaid. Veelgi otsesem seos

${ }^{3}$ https://et.wikipedia.org/wiki/Keel (7. I 2018). 
keele kõnelejaskonnaga on keele sotsiaalsetel funktsioonidel (instrumentaalne funktsioon; sotsialiseerimine, identiteedi kujundamine; suhtlusnormide ja keelekasutusnormide kujundamine; keelekollektiivi mälu edasikandmine; tegelikkuse kategoriseerimine).

Selles, kuidas lingvist keelt uurib, võib eristada kahte põhilist lähenemist. Ühelt poolt võib keelt tõesti vaadelda autonoomse süsteemina, abstraktse idealisatsioonina, pööramata tähelepanu kasutuse varieerumisele. Sellist lähenemist rõhutas strukturalismi rajaja Ferdinand de Saussure, ja see ongi omane ennekõike strukturalistlikule ja generatiivsele keeleteadusele, samuti keeletüpoloogiale. Sellise lähenemise puhul võib suhe uuritava keele kõnelejaskonda puududa (nagu joonisel 2) või olla minimaalne ja teisejärguline (nagu joonisel 3).

Teiselt poolt on aga olemas hulk funktsionaalseid suundi, mis uurivad keelt selle funktsioonidest lähtuvalt, arvestades kasutust, varieerumist, keeleväliseid tegureid (kasutajaid, situatsiooni, konteksti). Siia kuuluvad näiteks sotsiolingvistika, murdeuurimine, võrdlev-ajalooline keeleteadus, kasutuspõhine keeleuurimine, keele dünaamika ja varieerumise uurimine, vestlusanalüüs, pragmaatika, kriitiline tekstianalüüs, kontaktlingvistika, areaallingvistika, etnolingvistika, esimese ja teise keele omandamise uurimine. Nendes suundades on keel uurimisobjektina küll esiplaanil, kuid kasutajad rohkem või vähem taustaks, mis loob ka põhja R-osa suuremaks kohaloluks (joonis 5).
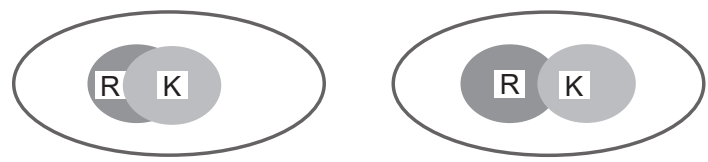

Joonis 5. K- ja R-osa funktsionalistlikes suundades.

\section{Milleks rahvusriigile keeleteadus?}

Keeleteadus on Eestile vajalik vähemalt neljal põhjusel: 1) eesti keele uuringute vajalikkus rakenduste jaoks, 2) eesti keele ja sugulaskeelte uurimise rahvust ühendav roll, 3) Eesti keeleteaduse väärtustamine osana Eesti ja maailma teadusest, 4) keeleteadlaste vastutustunne.

1. Eesti keele uuringute vajalikkus rakenduste jaoks. Eesti keel on Eesti riigi keel, Eesti ühiskonda ühendav keel. „Kirjakeel on Eesti ühiskonna taristu - vältimatu nii haridus- ja haldussüsteemi kui ka kultuuri toimimiseks üldisemalt" (Ehala 2017). Eesti keelel on harukordselt tugev positsioon ametliku keelena, haridus- ja teaduskeelena, keeletehnoloogias: „Eesti keel kuulub kõnelejate arvult maailma 400 suurima keele hulka, on 200 riigikeele seas, 50 kõrghariduskeele seas, 30 keeletehnoloogiaga keele seas ja 24 Euroopa Liidu ametliku keele seas" (Arengukava 2018: 3).

Eesti keele uuringud (ahelas alusuuringud > rakendusuuringud > rakendused) on vajalikud keele edukaks toimimiseks kõigis olulistes kasutusvaldkondades. Olgu siin loetletud mõningad rakenduslike uuringute valdkonnad: keelekorraldus (üld- ja oskuskeelekorraldus, nimekorraldus), arvutilingvis- 
tika, keeletehnoloogia, leksikograafia, kriitiline tekstianalüüs, emakeeleõpetus, eesti keele õpetamine teise keelena, õppijakeele uurimine, kontrastiivuuringud, tõlketeadus. Keeleteadus peab andma ka taustainfot ja soovitusi keelepoliitikale, aitama kaasa keele sotsiaalsete funktsioonide tõhusale täitmisele (nii esimese kui ka teise keelena) ja lahendama aktualiseeruvaid keeleküsimusi.

2. Eesti keele ja sugulaskeelte uurimise rahvust ühendav roll. Keeleteadus on osa humanitaar- ja rahvusteadustest, mille jaoks on oluline identiteet, juured, seosed meie teiste inimest ja rahvust uurivate ja väärtustavate teadustega.

3. Keeleteadus kui osa Eesti ja maailma teadusest. Taasiseseisvunud Eestis on pandud suurt rõhku teaduse arendamisele, rahvusvahelistumisele ja järelkasvule. Eesti keele arendustegevusi toetavad riiklikud programmid. Nii on ka keeleteadlastel, mille üle uhkust tunda. On ilmunud või ilmumas mitmed suurteosed (kirjakeele seletussõnaraamat, õigekeelsussõnaraamat, murdesõnaraamat, „Eesti keele varamu” sari). Eesti keeleteadus on muutunud nii Eestis kui ka maailmas nähtavaks, selle vaieldamatuks näitajaks on Tartu Ülikooli lingvistika 101.-150. koht aastatel 2016 ja 2017 ülikoolide edetabelis QS World University Rankings ${ }^{4}$ - kõrgeim positsioon, mis Eesti teadusalad saavutanud on. Edu tuleb hoida, eesmärgiks peaks olema eesti keele uurimise tugeva jätkamise ja tippkompetentsi koondamine Eestisse. Teiselt poolt tuleb teha ka rahvusvahelist koostööd, arendada üldkeeleteadust, muude keelte uurimist ja interdistsiplinaarseid uuringuid.

4. Keeleteadlaste vastutustunne. Elu on näidanud, et K-osa toobki enamasti kaasa R-osa. Keeleteadlased peavad rahvuskeelt oma südameasjaks ja tegutsevad selle nimel. Kui vaadata viimaseid aastakümneid, näeme, et laulva revolutsiooni ajal olid paljud keeleteadlased seotud keeleseaduse (1989) ettevalmistamisega, mis andis eesti keelele riigikeele õigused. Seejärel on suures osas keeleteadlastest koosneval Eesti Keelenõukogul olnud juhtiv roll kahe eesti keele arengukava (EKAS 2004, EKA 2011) koostamisel ja seiramisel. Selle loo kirjutamise ajal käib arutelu uue arengukava (Arengukava 2018) üle. Me korraldame eesti keelt populariseerivaid üritusi ja muid algatusi, osaleme tele- ja raadiosaadetes, kirjutame artikleid ja raamatuid, esineme koolides ja diskuteerime poliitikutega, võtame sõna avalikus ja sotsiaalmeedias.

Kus on siis rahvuse koht tänapäeva Eesti lingvisti peas? Kindlasti leidub siin varieerumist seinast seina, kuid keskmist suhet võiks iseloomustada joonis 6: K-osaga kaasneb R-osa, neil on märgatav kokkupuuteala, ilma et kumbki komponent teist kataks.

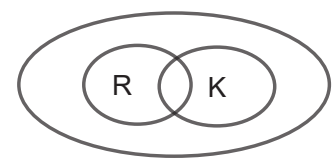

Joonis 6. K- ja R-osa keskmine suhe tänapäeva Eesti keeleteaduses.

${ }^{4} \mathrm{http} / / /$ www.delfi.ee/news/paevauudised/eesti/suur-hupe-edetabelis-tartu-ulikool-purib-maailma-ulikoolide-hulgas-aina-korgemale?id=78499903 (7. I 2018). 


\section{Kirjandus}

Arengukava 2018 = Eesti keelevaldkonna arengukava 2018-2027 (eelnõu). Haridus- ja Teadusministeerium, 2017.

Eh al a, Martin 2017. Eesti kirjakeel kui taristu. - Postimees 27. X.

EKA 2011 = Eesti keele arengukava 2011-2017. Tallinn.

EKAS 2004 = Eesti keele arendamise strateegia 2004-2010. Tartu.

He in e, Bernd, Ku t e v a, Tania 2002. World Lexicon of Grammaticalization. Cambridge: Cambridge University Press.

Helle, Anton Thor 2006 [1732]. Lühike sissejuhatus eesti keelde. Saksa keelest tõlkinud ja järelsõnad kirjutanud Annika Kilgi ja Kristiina Ross. Tallinn: Eesti Keele Sihtasutus.

Schmidt-Brücken, Daniel, Schuster, Susanne, Stolz, Thomas, Warnke, Ingo, W i e n berg, Marina (toim) 2015. Koloniallinguistik. Sprache in kolonialen Kontexten. (Koloniale und Postkoloniale Linguistik / Colonial and Postcolonial Linguistics 8.) Berlin-Boston: De Gruyter Mouton.

\section{Is there a place for a nation in a linguist's brain?}

Keywords: linguistics, ethnos, nation state, Estonian

The article discusses whether a linguist's attitude to language as an object of research may entail a valorising attitude to a language community, its past, present and future. Typical proportions and relations between the analytical and ethnic approaches to the language are broken down by periods of research of Estonian, language components and schools of linguistics. The functions of linguistics in a nation state are also pointed out.

Helle Metslang (b. 1950), PhD, University of Tartu, Professor of Modern Estonian Language, helle.metslang@ut.ee 